\title{
SISTEM AKUISISI DATA SOLAR CELL BERBASIS MIKROKONTROLER DAN LABVIEW
}

\author{
Benriwati Maharmi *, Febri Ferdian, Fadhli Palaha \\ Jurusan Teknik Elektro, Sekolah Tinggi Teknologi Pekanbaru (STTP) \\ Riau 28289, Indonesia \\ Email: benriwati_m@yahoo.com
}

\begin{abstract}
ABSTRAK
Energi terbarukan merupakan sumber energi berkelanjutan yang bisa dimanfaatkan sebagai energi alternatitif, salah satunya sinar matahari dengan menggunakan solar cell untuk menghasilkan energi listrik. Untuk memudahkan melakukan monitoring data solar cell, maka penelitian ini digunakan layar monitor komputer untuk menampilkan hasil monitoring akuisisi data pada panel solar cell 20 WP yang menggunakan, sensor arus ACS712, sensor tegangan FZ0430, sensor temperature LM35 dan sensor intensitas cahaya MAX44009. Penelitian ini dilakukan dengan membuat simulasi menggunakan LabVIEW dan mikrokontroler arduino uno sebagai pengakuisisi data, sehingga diperoleh pengukuran tegangan rata-rata yang dihasilkan oleh solar cell adalah $13,12 \mathrm{~V}$ dengan tegangan tertinggi sebesar 14,38V dan arusnya antara $0,11 \mathrm{~A}-0,79 \mathrm{~A}$. Semakin lama solar cell beroperasi semakin tinggi suhu yang terukur menggunakan sensor suhu yaitu sebesar $53.1{ }^{\circ} \mathrm{C}$ pada jam 17.00 wib, dan intensitas cahaya pada siang hari akan besar yaitu pada jam 11.00 wib - 13.30 wib dengan intensitas cahaya rata-rata 75.693 lux.
\end{abstract}

Kata kunci : Akuisisi Data, Solar Cell, LabVIEW, Mikrokontroler

\section{ABSTRACT}

Renewable energy is a source of sustainable energy that can be used as alternative energy such as the solar cells to produce electrical energy. To make it easier to monitor solar cell data, this study used a computer monitor screen to display the results of the monitoring data acquisition on a $20 \mathrm{WP}$ solar cell panel that uses ACS712 current sensor, FZ0430 voltage sensor, LM35 temperature sensor and MAX44009 light intensity sensor. This research was conducted by making a simulation using LabVIEW and arduino uno microcontroller as data acquisition. The results were revealed the average voltage measurement produced by the solar cell of $13.12 \mathrm{~V}$ with the highest voltage of $14.38 \mathrm{~V}$ and the current of $0.11 \mathrm{~A}-0,79 \mathrm{~A}$. The longer of solar cell operates the higher temperature was $53.1^{\circ} \mathrm{C}$ at $17.00 \mathrm{WIB}$. The intensity of light during the days was large at $11.00 \mathrm{WIB}-13.30$ WIB with an average light intensity of 75.693 lux.

Keywords: Data Acquisition, Solar Cell, LabVIEW, Microcontroller

\section{PENDAHULUAN}

Energi terbarukan merupakan sumber energi yang dihasilkan dan berasal dari sumber energi terbarukan yang bisa dimanfaatkan secara bekelanjutan jika dikelola dengan baik, contoh energi terbarukan adalah panas bumi, angin, bioenergi, sinar matahari, [1-2] Sinar matahari merupakan sumber energi terbarukan yang melimpah di Indonesia yang merupakan negara tropis, dimana matahari bersinar sepanjang tahun. Mengoptimalkan potensi alam dengan memanfaatkan sinar matahari sebagai sumber listrik menggunakan solar cell yang menghasilkan tegangan arus searah (Direct Current/DC). Tegangan DC yang dihasilkan bisa dimanfaatkan secara langsung pada beban DC atau beban arus bolak balik 
(Alternating Current/AC) dengan mengkonversi tegangan DC ke tegangan AC menggunakan inverter. Peralatan listrik yang menggunakan inverter konvensional bisa mengalami gangguan dan kerusakan akibat dari harmonisa [3]. Inverter dengan modifikasi five level pulse Width Modulation (PWM) menghasilkan tegangan keluaran dan arus dengan nilai harmonisa yang lebih kecil dibandingkan dengan inverter konvensioal [4,9].

Pada Pembangkit Listrik Tenaga Surya (PLTS) dengan menggunakan solar cell, Asy'ari melakukan penelitian tentang hubungan antara intensitas matahari terhadap daya keluaran secara manual dengan menggunakan lumen meter, dan multimeter untuk mengukur arus dan tegangan keluaran solar cell [5]. Pengukuran yang dilakukan dengan cara manual memerlukan waktu yang lama dan tidak efisien, apalagi kalau dilakukan untuk pengukuran sistem yang banyak tentu membutuhkan tenaga kerja dan waktu yang lama. Maka solusi yang dibutuhkan adalah membuat sistem yang otomatis untuk memudahkan dan efisensi dalam segi waktu dan tenaga dalam pencatatan dan pengukuran menggunakan akuisisi data. Untuk akuisisi data sendiri, sekarang ini sudah banyak digunakan secara luas, tidak hanya di bidang elektronika tapi pada semua sistem yang ada hubungannya dengan teknologi [6]. Akuisisi data pada solar cell akan memudahkan pengumpulan data-data dalam monitoring kinerja sistem yang dibutuhkan untuk waktu yang lama, dimana pengukuran perlu dilakukan menggunakan parameter masukan dan keluaran untuk melihat karakteristik dan kinerja dari solar cell. Parameter yang digunakan yaitu intensitas cahaya matahari dengan satuan lux atau Watt $/ \mathrm{m}^{2}$, suhu $\left({ }^{\circ} \mathrm{C}\right)$, arus (Amper) dan tegangan (Volt). Asriyadi melakukan penelitian data logger menggunakan device myRIO sebagai interface untuk membandingkan dengan pengukuran secara manual pada kondisi lingkungan yang tidak tetap [7].

Selanjutnya diperlukan karakterisasi panel solar cell yang sesuai terhadap berbagai kondisi real dilapangan dengan metode yang effective dan efisien seperti menggunakan simulasi berbasiskan microcontroller [8-13]. Pada penelitian ini penulis merancang aplikasi untuk menampilkan data karakteristik solar cell dan sensor yaitu sensor tegangan, sensor arus, sensor suhu dan sensor intensitas cahaya matahari dengan berbasis komputerisasi menggunakan aplikasi LabVIEW dan arduino uno sebagai akuisisi data sistem yang akan diuji, sehingga memudahkan dalam melakukan pengukuran karena sistem akuisisi data yang dibuat sudah ada terangkai langsung pada solar cell.

\section{METODA PENELITIAN}

\section{Solar Cell}

Photovoltaic atau solar cell merupakan komponen elektronika yang dapat merubah energi cahaya menjadi listrik, penemunya Edmond Becquerel dan kawan-kawan pada abad ke 18 [14]. Sel surya atau solar cell merupakan komponen yang terbuat dari silicon type $\mathrm{P}$ yang bersifat positif (foton) dan jenis $\mathrm{N}$, negative (electron) sehingga menyebabkan terciptanya pengkutuban (polarisasi), dengan menyambungkan kedua jenis silicon melalui suatu penghantar luar maka terjadi beda potensial antar keduanya dan mengalirkan arus searah [15]. Pada gambar 1 dapat dilihat prinsip kerja photovoltaics.

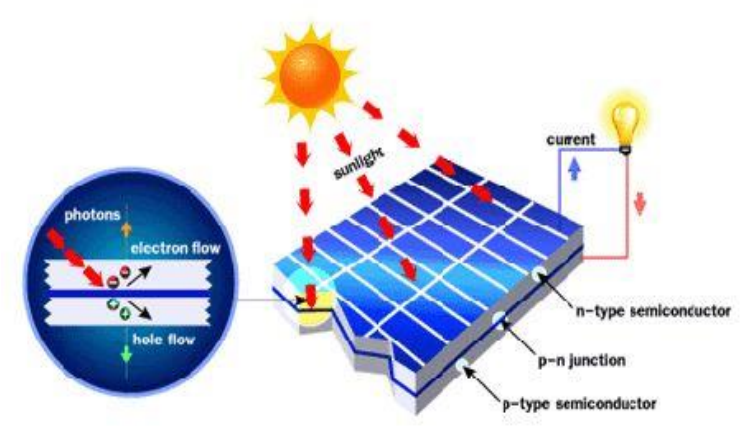

Gambar 1. Prinsip kerja sel photovoltaic

Pada penelitian ini akan dilakukan perancangan sistem akuisisi data pada solar cell, 20 Watt Peak (WP) type Mono, Arus listrik maksimum $1.14 \mathrm{~A}$, dengan tegangan maksimum $17,5 \mathrm{~V}$, serta toleransi \pm 3 $\%$. Sistem monitoring data menggunakan komputer, dimana sistem dibuat menggunakan mikrokontroler Arduino uno sebagai akuisisi data dan software LabVIEW. Layar monitor komputer digunakan untuk menampilkan hasil monitoring akuisisi data pada panel solar cell yang menggunakan, sensor arus ACS712, sensor tegangan FZ0430, sensor suhu IC LM35 dan sensor intensitas cahaya menggunakan photodetector MAX44009. Pada gambar 2 dapat dilihat blok diagram penelitian sistem akuisisi data pada solar cell. 


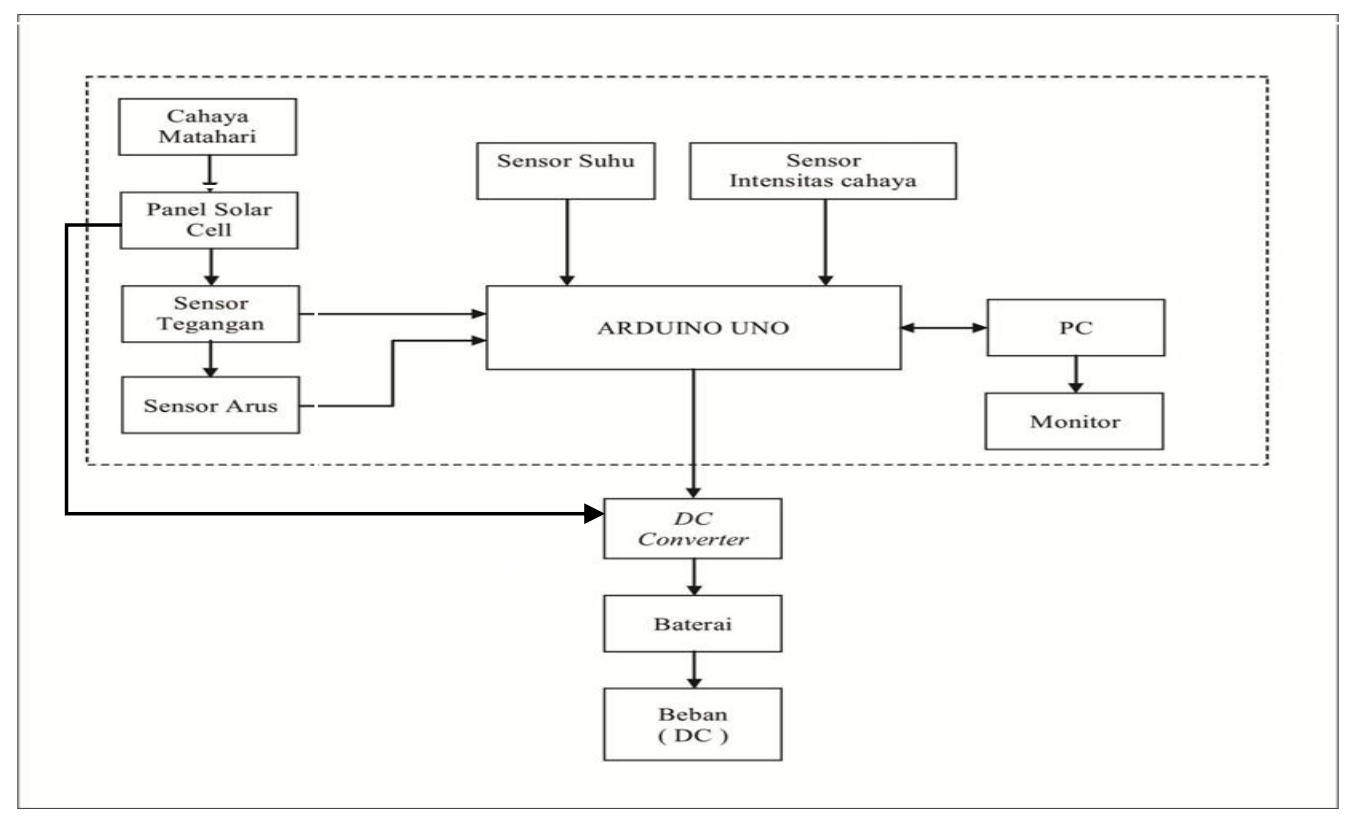

Gambar 2. Blok Diagram akuisisi data solar cell

Modul surya akan menyerap cahaya matahari yang kemudian diubah menjadi listrik melalui proses photofoltaic. Listrik yang dihasilkan berupa arus searah (DC) kemudian diteruskan ke sensor tegangan, sensor arus, sensor suhu dan sensor intensitas cahaya. Sensor disini berfungsi untuk mengetahui besaran atau nilai yang terukur pada panel solar cell. Tegangan yang dihasilkan oleh solar cell akan masuk ke DC converter sebelum masuk ke baterai sebagai penyimpan energi listrik yang dihasilkan. Fungsi sensor tegangan adalah mengukur nilai tegangan pada panel solar cell. Sensor arus berfungsi sebagai pengukur nilai arus yang mengalir ke beban. Sensor suhu berfungsi sebagai pendeteksi nilai suhu yang terdapat pada panel solar cell tersebut. Sensor suhu yang digunakan pada penelitian ini adalah IC LM35 yang berfungsi untuk mengubah besaran suhu menjadi besaran listrik dalam bentuk tegangan. Sensor suhu IC LM35 memiliki kemudahan dalam perancangan dibandingkan dengan sensor yang lain, juga dapat dengan mudah dihubungkan dengan rangkaian kendali dan tidak memerlukan penyetelan lanjutan. IC LM35 ini memiliki tingkat keakuratan yang tinggi, dengan keluaran impedansi yang rendah serta linieritas yang tinggi. Rangkaian dasar IC LM35 seperti pada gambar 3 [16].

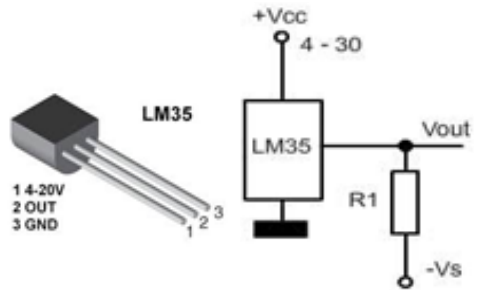

Gambar 3.Rangkaian dasar IC LM35

Sedangkan sensor intensitas cahaya menggunakan photodetector MAX44009 yang berfungsi mengukur intensitas cahaya matahari seperti pada gambar 4 [17].

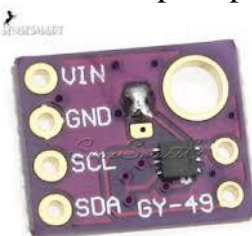

Gambar 4. Photodetector MAX44009

\section{Diagram blok LabVIEW}

Diagram blok LabVIEW merupakan bagian penting dalam perancangan monitoring panel solar cell ini. Dimana tanpa diagram blok yang diprogram, front panel tidak dapat berfungsi. Pada perancangan diagram blok terbagi beberapa bagian yang penting yaitu seperti pada gambar 5 . 


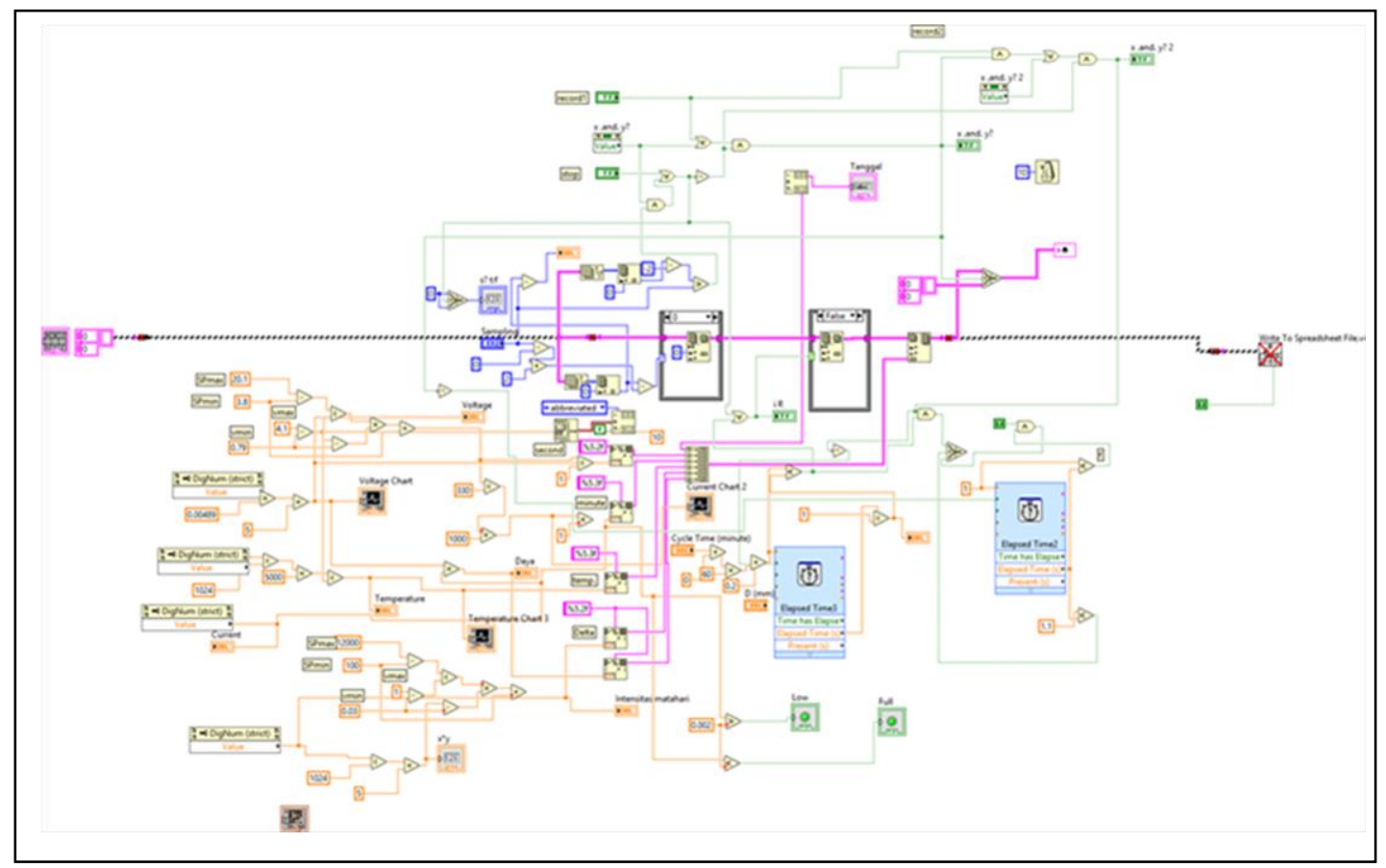

Gambar 5. Bagian Pengolahan Data dan Input Tabel

Bagian pengolahan data pada LabVIEW merupakan suatu hal yang penting, karena terdapat pengolahan data dari arduino, dimana pada bagian ini terdapat persamaan input data tabel berupa perkalian tegangan dan arus, kalibrasi tiap sensor dapat dilakukan disini. Data yang dari arduino dikirim dalam satu data, sehingga saat sampai di LabVIEW akan dilakukan pemisahan data berdasarkan inisial data.

\section{HASIL DAN PEMBAHASAN}

Pengambilan data dilakukan mulai dari pukul 09.00 WIB untuk mendapatkan data dengan intensitas sinar matahari yang terik di pagi hari. Hal ini dilakukan karena pada bulan Mei dan Juni dengan intensitas matahari tinggi. Data yang ditampilkan adalah 17 sampel data pada pengujian 09.00 - 17.00 WIB dengan sampling data setiap 30 Menit.

\section{Pengujian Tegangan dan Arus}

Pengujian tegangan dan arus menggunakan Software LabVIEW pada solar cell. Dari hasil monitoring data tegangan dan arus yang dihasilkan oleh solar cell dapat dilihat pada grafik pada gambar 6.

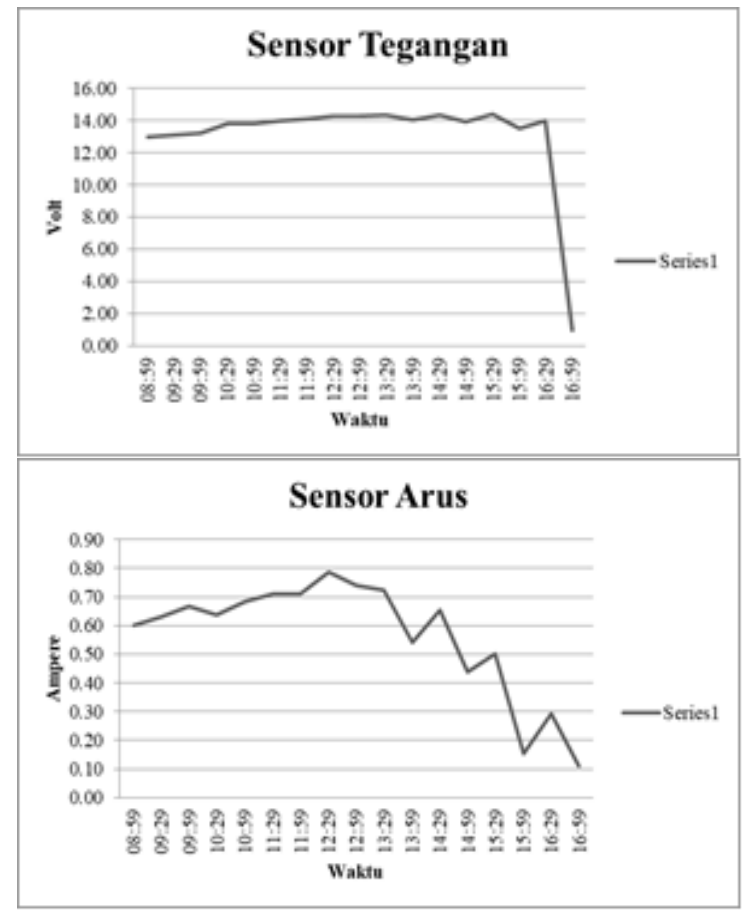

Gambar 6. Grafik Sensor Tegangan dan sensor arus terhadap waktu 
Grafik hasil monitoring tegangan matahari pada solar cell yang dilakukan selama rentang waktu delapan jam, diperoleh tegangan rata-rata 13,12 volt dengan tegangan terendah yaitu pukul 17.00 WIB sebesar $0.95 \mathrm{~V}$ dan tegangan maksimum sebesar 14.38 V. Pada pengujian sensor arus diperoleh arus yang mengalir dari solar cell ke batrai sebagai tempat pemyimpanan energi yang dihasilkan sebelum disalurkan ke beban adalah antara $0,11 \mathrm{~A}$ sampai 0,79 A.

\section{Pengujian Sensor Suhu}

Pada pengujian sensor suhu LM35 menggunakan Software LabVIEW pada solar cell. Dasil pengukuran suhu yang ditampilkan pada gambar 7, bahwa suhu solar cell akan naik tergantung intensitas cahaya matahari dan lamanya solar cell beroperasi.

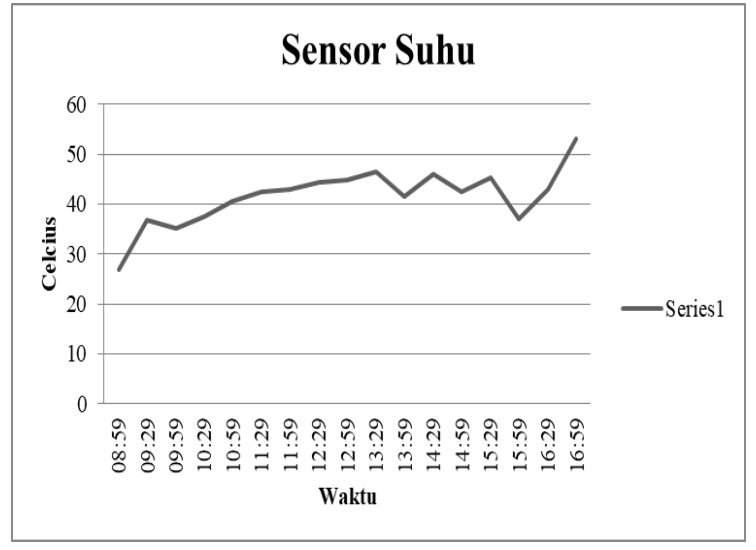

Gambar 7 Grafik Sensor Suhu terhadap waktu

Grafik diatas menunjukkan pengaruh suhu dari pukul 09.00 sampai pukul 17.00. Dari hasil pengujian dan pengukuran suhu pada solar cell menggunakan sensor suhu, diperoleh suhu terendah pukul 09.00 WIB sebesar $26.8^{\circ} \mathrm{C}$ dan suhu tertinggi pukul 17.00 WIB sebesar $53.1^{\circ} \mathrm{C}$.

\section{Pengujian Sensor Intensitas Cahaya}

Pengujian sensor intensitas cahaya menggunakan Software LabVIEW pada solar cell. Grafik pengujian dapat dilihat pada gambar 8 .

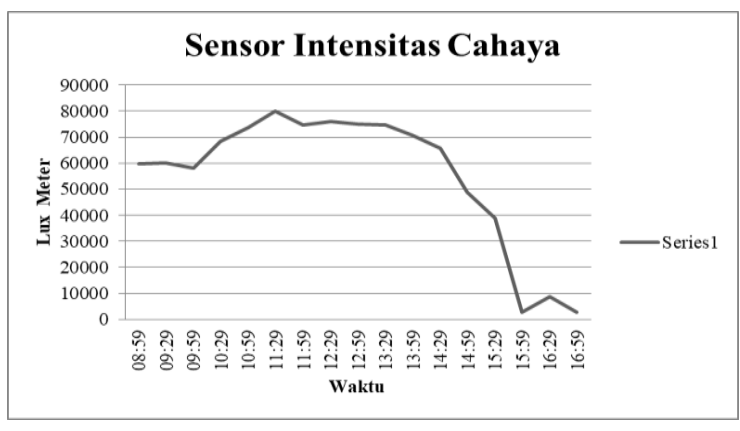

Gambar 8. Grafik Sensor Intensitas Cahaya dengan waktu

Hasil monitoring intensitas cahaya matahari yang dilakukan dapat dilihat bahwa intensitas cahaya akan semakin besar pada saat matahari bersinar disiang hari pada jam 11.00 wib - 13.30 wib dengan intensitas cahaya rata-rata 75.693 lux.

\section{KESIMPULAN}

1. Pada pengujian monitoring data logger menggunakan LabVIEW dengan mikrokontroler arduino uno sebagai pengendali sistem diperoleh pengukuran tegangan rata-rata yang dihasilkan oleh solar cell adalah 13,12 V dengan tegangan tertinggi sebesar $14,38 \mathrm{~V}$ dan arusnya antara $0,11 \mathrm{~A}-0,79 \mathrm{~A}$

2. Semakin lama solar cell beroperasi semakin tinggi suhu yang terukur menggunakan sensor suhu yaitu sebesar $53.1{ }^{\circ} \mathrm{C}$ pada jam 17.00 wib, dan intensitas cahaya pada siang hari akan besar yaitu pada jam 11.00 wib - 13.30 wib dengan intensitas cahaya rata-rata 75.693 lux.

\section{DAFTAR PUSTAKA}

[1] Peraturan Presiden Republik Indonesia nomor 5 Tahun 2006, Bab I, Pasal 1:4, tentang Kebijakan Energi Nasional.

[2] Undang-undang Republik Indonesia Nomor 30 tahun 2007, Bab I, Pasal 1:6, tentang Energi

[3] Maharmi, Benriwati, Perancangan Inverter Satu Fasa Lima Level Modifikasi Pulse Width Modulation, Jurnal Teknologi Elektro, Vol.8 No1 Januari 2017, Hal. 24-31, Jakarta, Universitas Mercu Buana

[4] Maharmi, Benriwati, Simulation Of Single Phase Five Level Inverter Based Modified Pulse Width Modulation Approach, 
International Journal of Ocean Mechanical and Aerospace-Science and Enginering. vol. 37, November 2016, page 15-20.

[5] Asy’ari, Hasyim, Jatmiko, Angga, Intensitas Cahaya Matahari Terhadap Daya Keluaran Panel Surya, Simposium Nasional ke-11 RAPi, 2012.

[6] J. Rajmon dan Pitica, Data Logger for Signal analysis and failure prediction, in International Symposium for Design and Technology in Electronic Packaging (SIITME) IEEE 16 ${ }^{\text {th }}, 2010$

[7]. Asriyadi, Evaluasi sensoryang digunakan untuk perancangan sistem data logger pada solar panel, Elektrika, vol 13,No. I/Mei 2016, hal.42-59

[8] M. Fuentes, M. Vivar, J. M. Burgos, J. Aguilera, J. A. Vacas, Design of an accurate, low cost autonomous data logger for PV system monitoring using Arduino that complies with IEC standards, Solar Energy materials and solar cells, Volume.130, pp 529 - 543. (2014).

[9] Mellit, M. Benghanem, S.A. Kalogirou, Modeling and simulation of a stand-alone photovoltaic system using an adaptive artificial neural network: Proposition for a new sizing procedure, Renewable Energy, Volume 32, Issue 2, February 2007, Pages 285-313.

[10] Saraswati Teli, Mani.C, Smart real time embedded Arduino based data acquisition system, International Journal Of Research in Engineering and Technology, Volume 04, pp.258-262, 2015.

[11] Kenji Kobayashi, Ichiro Takano, Yoshio Sawada, A study of a two stage maximum power point tracking control of a photovoltaic system under partially shaded insolation conditions, Solar Energy Materials \& Solar Cells, Vol 90 (2006) halaman 975-2988.

[12] E. Koutroulis, K. Kalaitzakis, and N. C. Voulgaris, Development of a microcontroller-based, photovoltaic maximum power point tracking control system, IEEE Trans. Power Electron., vol. 16, no. 21, pp. 46-54, 2001.

[13] Farid Touati, M. A. Al-Hitmi, Noor Alam Chowdhury, Jehan Abu Hamad, Antonio J. $\mathrm{R}$ San Pedro Gonzales, Investigation of solar $P V$ performance under Doha weather using a customized measurement and monitoring system, Renewable Energy, Volume 89, pp 564-577, 2016.

[14]. Sudrajat, Adjat., 2007, Sistem-Sistem Pembangkit Tenaga Surya, Jakarta: BPPT Press.

[15]. Lubis, Abubakar, Sudrajat, Adjat., 2006, Listrik Tenaga Surya Fotovoltaik, Jakarta: BPPT Press.

[16]. Data sheet, 2000, LM35 Precision Centigrated Temperature Sensors. National Semiconductor corporation.

[17]. Data Sheet, 2011, MAX44009 Industry's Lowest-Power Ambient Light Sensor with $A D C$, Maxim Integrated, sam Jose USA. 